Biological and Clinical Sciences Research Journal

ISSN: 2708-2261

www.bcsrj.com

DOI: https://doi.org/10.54112/bcsrj.v2021i1.53

Biol. Clin. Sci. Res. J., Volume, 2020: 53

Review Article

\title{
THERAPEUTIC ACTIVITIES OF GARLIC CONSTITUENT PHYTOCHEMICALS
}

\author{
ASHFAQ F, ALI Q, HAIDER MA, *HAFEEZ MM, MALIK A \\ Institute of Molecular Biology and Biotechnology, The University of Lahore, Lahore, Pakistan \\ Corresponding author email: mansoorhafeez140@gmail.com
}

(Received, $4^{\text {th }}$ March 2020, Revised $31^{\text {th }}$ January 2021, Published $2^{\text {nd }}$ February 2021)

\begin{abstract}
Garlic (Allium sativum L.) has medicinal value but also an important dietary component for centuries. It belongs to the family of Liliaceae, which is mostly grown and found in Ethiopia and Africa. Ethiopian garlic has been mostly used in traditional medicines. Inhibitory activity of garlic extract has been reported by various researchers for Lactobacillus acidophilus, Staphyloccocus aureus, Nocardia asteroids, pseudomonas aeruginosa, actinomyces viscosus, veillonella alcaligens bacterial strains. The garlic paste and lime was used for mouth sore, sore throat and also can be used in toothpaste to prevent dental caries. The present review describes the potential of garlic phytochemicals for the improvement of the immune system against diseases in humans.
\end{abstract}

Keywords: garlic, Allium sativum, antibacterial, antifungal, herbal medicine

\section{Introduction}

It is the one of the first crop in early 5000 years ago which was domesticated by human. During 1970's garlic was tested on 10 different species and shows inhibitory activities against Salmonella, S. Aureus, Mycobacterium and proteus species. Garlic is an antibacterial as well as anti-fungal agent (Block, 2010; Rivlin, 2001). As allicin is present in garlic which has its own molecular properties and several therapeutic effects and it is also basically a defence molecule. Allicin (allyl thiosulfinate) is a thiolcontaining protein which is a fluid like compound present in garlic. Allicin produce smell of garlic (Agarwal, 1996; Amagase et al., 2001). Garlic is the most basic spice used in Indian \& Pakistani foods. Basically due to the presence of allicin in garlic it became effective against gram positive and gram negative bacteria. Garlic has also the ability to kill streptococci. It has a pungent odor, also contain sulphur compounds. Fresh crushed garlic is used as an effective medicinal extract against common pathogenic (Corzo-Martínez et al., 2007; Flora, 2009). During 1940's the main purpose of using herb plants was to used for herbal medicines which are more effective against several infections and diseases. Garlic is also good for heart and stomach disease, also for wound and sexually transmitted diseases (Banerjee and Maulik, 2002). It is also good against the anthrax disease. Garlic also helps to lower down the cholesterol level. The use of garlic increases the shelf life of food. Garlic is also used in the form of capsule and powder form. Louis Pasteur first described the antibacterial activities of garlic juice. Garlic has antibiotic resistance against several bacteria such as E. coli, Salmonella, Shigella Senterae, Pseudomonas, etc. The alliinase enzyme turns into allicin (Kim and Kyung, 2003; Urs et al., 1994). These are responsible for the smell of garlic and garlic has also several antioxidant properties due to antioxidant properties. Antioxidants good for cancer, it protect cells from free radical and prevent the damage of cells due to oxidation. Garlic is not only antibacterial but also has antifungal \& antiprotozoal properties (Jansen et al., 1989; Kim and Kyung, 2003). When garlic is cooked the allicine of garlic destroys but in case we use raw garlic which is more effective then cooked garlic. It has antiinflammatory, hypoglycaemia, also consist of hormone like effects. Garlic is oldest medicinal plant used in foods and as a medicine in different ways (Shimon et al., 2007; Wang et al., 2011).

\section{Chemical properties}

Allicin is not present in fresh garlic clove. It is odourless amino acid, not stable at room temperature, contains sulphur, is anti-hypertensive, antioxidant, and also has lipid lowering properties. Diallyl disulfide is organosulfur compound with light yellowish color. Due to this compound, most bacteria are sensitive to extracts from plants such as clove, garlic, mustard, onion, organo, turmeric etc. Garlic can also cause adverse reaction on our health such as allergy, cardiovascular problem dermartitis and bleeding under controlled manner (Shimon et al., 2007; Zhou and Wang, 2009). Adverse reactions are due to the improper use of garlic and poor remedies. Garlic allergy has been manifested as rhinitis, 
asthma, anaphylaxis contact dermatitis and pemphigus. Diallyl disulfide $\left(\mathrm{C}_{6} \mathrm{H}_{10} \mathrm{~S}_{2}\right)$ and allylpropyle disulfide $\left(\mathrm{C}_{6} \mathrm{H}_{12} \mathrm{~S}_{2}\right)$ are the basic components of garlic which are causative of allergies. Allylpropyl is the strongest sensitizer. Garlic consisted of anti-mitotic potential against colon neoplassic lesions in vivo and colon tumour cell growth in vitro. It inhibits colon cancer. It also has anti obesity properties which directly mean it helps to increase the metabolic rate and in this way it lower downs the cholesterol level (Banerjee and Maulik, 2002; Shimon et al., 2007). Further study is needed to ascertain its toxicity against mammalian cells in vivo method may be used to confirm its potential side effects and efficacy. According to a survey $77 \%$ of the garlic is produced in India, South Korea, Egypt, Russia, , Myanmar, Ethiopia , USA , Bangladesh, \& Ukraine ( 1856 MMT ).

Organosulfur is derived from organic compounds, also present between the hot acidic volcanoes and deep in sea or ocean. Organosulphure is present in all living cells as the important amino acids, in the form of cysteine, cystine, and methionine they are important compounds of proteins (Chakraborty and Hancz, 2011; Tsai et al., 2012). Organosulfur consist of five cyclic compounds, isolated from the Allium sativum's leaves on the basis of physiochemicals. Organosulphur is mostly present in cruciferous vegetables, cauliflower, garlic, onion etc (Bayan et al., 2014; Iciek et al., 2009).

\section{Medical importance}

Garlic is a naturally a good source of therapeutic agents. Garlic is an ethno pharmaceutical drug but also proved to have therapeutic effects by different scientific studies allicin an organosulfur compounds, which prevent lipids from biosynthesis it was proved from a study that it damage the Candida albicans cell wall and inhibition of RNA in bacteria. For batter results garlic should be fresh and chemical free. Pure allicin has been found effective against isolates of Aspergillus in vitro study (Kuettner et al., 2002; Zhou and Wang, 2009). It is also good for hair growth, for flu and anti-febrile. Garlic also helps to get rid of intestinal tract of Giardia limbia which is a parasite live water stream and it causes infection (giardiasis) in small intestine (Harris et al., 2001; Sallam et al., 2004). Mostly homeo-pathies refers to take garlic cloves dissolved in water three times a day to get rid of Giardia. Antimicrobial activity: as the allicin consist of organosulfur compounds which are the most important for the antimicrobial property. Anti-helminthic activity: helminthic is basically infection caused by worm, the body is infectd with parasitic worm. Garlic has been used to treat the parasitic infections in humans and animals as well
(Hughes and Lawson, 1991; Ross et al., 2001). It has also shown antihelminthic activity against Ascaris lumbricoldes. Diallyl trisulphide has shown activity against several protozoans e.g. Trypanosoma species, Entamoeba bistolytica and giadia lamblia. The natural phytochemicals are present in it which is more effective alternative to antibiotics (Avato et al., 2000; Goncagul and Ayaz, 2010). It has ability to kill all natural streptococcus strains. Garlic is an immunosuppressive for down regulation of pro inflammatory responses. It is also reported that in both effects vivo and vitro the secretion pattern of cytokines from TH2 to TH1 (T helper cell type 2 and 1 ) interferon-gamma and nitric oxide production also under the certain conditions (Indu et al., 2006; Lai and Roy, 2004).

\section{Mechanism of action and synergistic effect of garlic}

It is studied that due the complex nature of plants, posses multiple mechanisms of action some of them are: viability, number of virulence factors, effect of antibiotic as resistance modifying agent. By the disruption of structure and membrane function, interruption in synthesis of DNA/RNA take place coagulation of cytoplasmic constituents occurs. Different agents involve in the interaction between synergistic effects and they are more efficient than other. There are several phases of effect active sites of bacterial cell are modified, degradation of antibiotics, membrane permeability increases, inhibits efflux pump (Gull et al., 2012; Indu et al., 2006).

\section{Antioxidant efficacy}

Garlic is rich in antioxidents which help to destroy the free radicals and particles that damage cell membrane and DNA which slows down the aging process. Garlic has complex chemical properties which have apparently opposite biological effects and play role in the antioxidants properties but if it is taken in higher it may cause toxic effects to heart and liver (Sallam et al., 2004; Yin and Cheng, 2003).

Antibacterial effect of garlic on dental plaque: dental plaque is the most common cause of dental disease. Plaque is actually the stick deposit on teeth consist of number of bacteria together. Plaque is not only bad for teeth but also bad for other health issues. Plaque removal is most important for the prevention of dental health and overall health (Chakraborty and Hancz, 2011; Sallam et al., 2004). Allium sativum is good alternatives to antibiotics it is effective against Escherichia coli, lactobacilli, klebsiella pneumonia, pseudomonas aereuginosa, mycobacterium tuberculosis. It responsive to minimum 4 to $32 \mathrm{ug} / \mathrm{ml}$. Pure extracts are more efficient against cecalbacteria. It is more effective against Candida Albicans which 
is mostly present in oral cavity. Garlic also acts synergistically with antibiotics (Lai and Roy, 2004; Ross et al., 2001).

Effect of garlic on human stomach: Helicobacter Pylori is most common bactreria in human stomach. Garlic has contribution in the treatment of $H$. pylori infection. H. pylori can cause severe gastritis which affect fundus, ulcer, malt lymphoma thyroid and skin are the common diseases or infections caused by $H$. pylori. The treatment of $H$. pylori consists of a proton pump inhibitor and two antibiotics amoxicillin and clarithyromycine for at least two weeks. People suffering from gastric disease have secretion of hydrochloric acid find it hard to tolerate (Flora, 2009; Londhe, 2011; Tsai et al., 2012). Garlic has been used world widely for several infections garlic is the best alternative of antibiotics. Several remedies have been discovered for drug development, these are pure standardize products obtained for herbal medicines. Secondary metabolites and phytochemicals seem to be the most important for screening purpose and drug development. Natural products have many advantages over to synthetic chemical drugs (Calo et al., 2015; Gyawali and Ibrahim, 2014).

Garlic for hairs: Garlic consists of vitamin B-6 and $\mathrm{C}$ which are good for hair growth. Garlic is also good for health scalp because of its antibacterial and antifungal properties and which is also good for dandruff. Garlic may cause burns on skin when applied on skin (Hajheydari et al., 2007; Khan et al., 2008).

For respiratory infections: in Russia garlic is also known as to be used for respiratory infection treatment by the physicians. It was also used as the inhalator for children. During World War 1 it was used for the soldier's treatment so garlic was named as Russian garlic or a natural antibiotic (Lissiman et al., 2014).

People use garlic as a basic spice in their cusine have low risk of blood vessel disease atherosclerosis and other heart diseases and also lower down the cholesterol (Bongiorno et al., 2008; Rouf et al., 2020).

Anti-biofilm activity: Multi drug resistance are the most common concern of the society nowadays. The anti biotic resistance have been increased the study based on nano-particles containing garlic extract. Bacterial biofilms are produced due to the drug resistant bacteria which add more resistance. Staphylococcus aureaus biofilms are commonly used for anti-bacterial activity studies. The study suggest GE-np are promising treatment and helpful for chronic infection treatment due to the presence of biofilm resistance (Girish et al., 2019; Vijayakumar et al., 2019).
Antiviral activity of garlic: influenza virus is the most common virus related to respiratory diseases because of its antigenic variations, there are very complex mutations which make it difficult to make the effective vaccine. Garlic is the one of most effective herbal against influenza virus (Bilal et al., 2020; Chattopadhyay and Naik, 2007).

Garlic and covid-19: Garlic fight against bronchitis infection and basically in corona virus bronchitus infection is the major symptom. As garlic is good for boosting immune system and also has several antibacterial properties to fight gainstbacteria(Chattopadhyay and Naik, 2007). But covid-19 is a new virus so many researches did research on garlic but didn't have any satisfied result, so garlic can be used for immunity boosting purpose to fight against covid-19 as garlic is good source for boosting immunity.

Role of garlic in wound healing: Several studies have shown that garlic extract increase the rate of wound healing also decrease the rate of infection. Fibrinogen is activated by allicin which is present in garlic and fibrinogen is most important for wound healing. Garlic containing ointment has more healing power (Alhashim and Lombardo, 2018; Ejaz et al., 2009).

Food pathogens sensitivity (garlic): The inhibitory activity of garlic against staphyllococus aureus, E. coli and listeria was measured by the turbidity method and is used garlic for stomach chills, flatulence, colics etc. Garlic is basically an inhibitor for food pathogens. Garlic increases the shelf life and decreases the chances of food poisoning and spoilage (Kuettner et al., 2002; Tsai et al., 2012).

Garlic for hypertension: Garlic is widely used for the lowering of blood pressure due to hypertension number of patients die. The herbal medicine have great impact on cardiovascular, still some evidences are not clearly identified that garlic provide a satisfied therapeutic advantage against some diseases. Two trials were done on 87 patients but not satisfied results found against hypertension (Gull et al., 2012; Reinhart et al., 2008).

Prevention of pre-eclampsia from garlic: Preeclampsia is a condition of high blood pressure in which oedema (fluid retention) and proteinuria (protein in urine) are major symptoms. It affects some women during second half of the pregnancy or may be after the delivery of their baby, women kidneys, brain and liver may also be affected and obesity occurs. Low number of evidence found that garlic is helpful to reduce the pre-eclampsia risk (Meher and Duley, 2006; Thangaratinam et al., 2011).

[Citation: Ashfaq, F., Ali, Q., Haider, M.A., Hafeez, M.M., Malik, A. (2021). Therapeutic activities of garlic constituent phytochemicals. Biol. Clin. Sci. Res. J., 2021: 53. doi: https://doi.org/10.54112/bcsrj.v2021i1.53] 
Garlic against tuberculosis: Tuberculosis is a kind of bacterial infection caused by Mycobacterium tuberculosis. It is globally most faced problem. According to homeopathy medicine garlic has the resistant properties against tuberculosis. As explained in various studies that garlic has anti-mycobacterium activities. Mycobacterium tuberculosis is the most sensitive and rapidly died (Nasiru et al., 2012; Rao et al., 1946).

Intestinal parasites: In several lab studies researchers suggested that raw or cooked in both forms garlic is effective against the intestinal parasites such as roundworm and ascaris lumbricoids (Ankri and Mirelman, 1999; Burke et al., 2009).

Ear pain and garlic: most children have ear problem they feel ear pain and it's called as otitis media. Mostly pain killers are given to the patient but now according to the latest herbal research it is suggested that ear drops containing garlic extract are good for pain relief (Ismaiel et al., 2012; Rose et al., 1990; Uzun et al., 2019) .

How to use it effectively: mostly at high temperature the allicin is killed. So add garlic in your recipes when your cooking is almost done.

\section{Conclusions}

It was concluded from all of our discussions that garlic is an important natural herb which may be used for improving immune system. It must be used on daily basis for combating with diseases to live healthy and long life. However, still more research studies are required to evaluate the potential of garlic as natural herbal medicine.

\section{Conflict of interest}

The authors declared absence of conflict of interest.

\section{References}

Agarwal, K. C. (1996). Therapeutic actions of garlic constituents. Medicinal research reviews 16, 111-124.

Alhashim, M., and Lombardo, J. (2018). Mechanism of action of topical garlic on wound healing. Dermatologic Surgery 44, 630-634.

Amagase, H., Petesch, B. L., Matsuura, H., Kasuga, S., and Itakura, Y. (2001). Intake of garlic and its bioactive components. The Journal of nutrition 131, 955S-962S.

Ankri, S., and Mirelman, D. (1999). Antimicrobial properties of allicin from garlic. Microbes and infection 1, 125-129.

Avato, P., Tursi, F., Vitali, C., Miccolis, V., and Candido, V. (2000). Allylsulfide constituents of garlic volatile oil as antimicrobial agents. Phytomedicine 7, 239-243.

Banerjee, S. K., and Maulik, S. K. (2002). Effect of garlic on cardiovascular disorders: a review. Nutrition journal 1, 1-14.
Bayan, L., Koulivand, P. H., and Gorji, A. (2014). Garlic: a review of potential therapeutic effects. Avicenna journal of phytomedicine $\mathbf{4}$, 1.

Bilal, M., Nasir, I., Tabassum, B., Akrem, A., Ahmad, A., and Ali, Q. (2020). Cytotoxicity and in-vitro antiviral activity of lectin from Crocus vernus 1 . against potato virus $\mathrm{Y}$. Applied Ecology and Environmental Research 18, 1301-1315.

Block, E. (2010). "Garlic other alliums," RSC publishing Cambridge.

Bongiorno, P. B., Fratellone, P. M., and LoGiudice, P. (2008). Potential health benefits of garlic (Allium sativum): a narrative review. Journal of Complementary and Integrative Medicine $\mathbf{5}$.

Burke, J., Wells, A., Casey, P., and Miller, J. (2009). Garlic and papaya lack control over gastrointestinal nematodes in goats and lambs. Veterinary Parasitology 159, 171-174.

Calo, J. R., Crandall, P. G., O'Bryan, C. A., and Ricke, S. C. (2015). Essential oils as antimicrobials in food systems-A review. Food control 54, 111-119.

Chakraborty, S. B., and Hancz, C. (2011). Application of phytochemicals as immunostimulant, antipathogenic and antistress agents in finfish culture. Reviews in Aquaculture 3, 103-119.

Chattopadhyay, D., and Naik, T. N. (2007). Antivirals of ethnomedicinal origin: structureactivity relationship and scope. Mini reviews in medicinal chemistry 7, 275-301.

Corzo-Martínez, M., Corzo, N., and Villamiel, M. (2007). Biological properties of onions and garlic. Trends in food science \& technology 18, 609-625.

Ejaz, S., Chekarova, I., Cho, J. W., Lee, S. Y., Ashraf, S., and Lim, C. W. (2009). Effect of aged garlic extract on wound healing: a new frontier in wound management. Drug and chemical toxicology 32, 191-203.

Flora, S. J. (2009). Structural, chemical and biological aspects of antioxidants for strategies against metal and metalloid exposure. Oxidative medicine and cellular longevity $\mathbf{2}$, 191-206.

Girish, V. M., Liang, H., Aguilan, J. T., Nosanchuk, J. D., Friedman, J. M., and Nacharaju, P. (2019). Anti-biofilm activity of garlic extract loaded nanoparticles. Nanomedicine: Nanotechnology, Biology and Medicine 20, 102009.

Goncagul, G., and Ayaz, E. (2010). Antimicrobial effect of garlic (Allium sativum). Recent

[Citation: Ashfaq, F., Ali, Q., Haider, M.A., Hafeez, M.M., Malik, A. (2021). Therapeutic activities of garlic constituent phytochemicals. Biol. Clin. Sci. Res. J., 2021: 53. doi: https://doi.org/10.54112/bcsrj.v2021i1.53] 
patents on anti-infective drug discovery 5, 9193.

Gull, I., Saeed, M., Shaukat, H., Aslam, S. M., Samra, Z. Q., and Athar, A. M. (2012). Inhibitory effect of Allium sativum and Zingiber officinale extracts on clinically important drug resistant pathogenic bacteria. Annals of clinical microbiology and antimicrobials 11, 1-6.

Gyawali, R., and Ibrahim, S. A. (2014). Natural products as antimicrobial agents. Food control 46, 412-429.

Hajheydari, Z., Jamshidi, M., Akbari, J., and Mohammadpour, R. (2007). Combination of topical garlic gel and betamethasone valerate cream in the treatment of localized alopecia areata: a double-blind randomized controlled study. Indian Journal of Dermatology, Venereology, and Leprology 73, 29.

Harris, J., Cottrell, S., Plummer, S., and Lloyd, D. (2001). Antimicrobial properties of Allium sativum (garlic). Applied microbiology and biotechnology 57, 282-286.

Hughes, B. G., and Lawson, L. D. (1991). Antimicrobial effects of Allium sativum L.(garlic), Allium ampeloprasum L.(elephant garlic), and Allium cepa L.(onion), garlic compounds and commercial garlic supplement products. Phytotherapy Research 5, 154-158.

Iciek, M., Kwiecień, I., and Włodek, L. (2009). Biological properties of garlic and garlic-derived organosulfur compounds. Environmental and molecular mutagenesis 50, 247-265.

Indu, M., Hatha, A., Abirosh, C., Harsha, U., and Vivekanandan, G. (2006). Antimicrobial activity of some of the south-Indian spices against serotypes of Escherichia coli, Salmonella, Listeria monocytogenes and Aeromonas hydrophila. Brazilian Journal of Microbiology 37, 153-158.

Ismaiel, A. A., Rabie, G. H., Kenawey, S. E., and EL-Aal, M. A. A. (2012). Efficacy of aqueous garlic extract on growth, aflatoxin B1 production, and cyto-morphological aberrations of Aspergillus flavus, causing human ophthalmic infection: topical treatment of A. flavus keratitis. Brazilian Journal of Microbiology 43, 1355-1364.

Jansen, H., Müller, B., and Knobloch, K. (1989). Alliin lyase from garlic, Allium sativum: Investigations on enzyme/substrate, enzyme/inhibitor interactions, and on a new coenzyme. Planta medica 55, 440-445.
Khan, M., Mostofa, M., Jahan, M., Sayed, M., and Hossain, M. (2008). Effect of garlic and vitamin B-complex in lead acetate induced toxicities in mice. Bangladesh Journal of Veterinary Medicine 6, 203-210.

Kim, J., and Kyung, K. (2003). Antiyeast activity of heated garlic in the absence of alliinase enzyme action. Journal of food science $\mathbf{6 8}$, 1766-1770.

Kuettner, E. B., Hilgenfeld, R., and Weiss, M. S. (2002). The active principle of garlic at atomic resolution. Journal of Biological Chemistry 277, 46402-46407.

Lai, P., and Roy, J. (2004). Antimicrobial and chemopreventive properties of herbs and spices. Current medicinal chemistry 11, 14511460.

Lissiman, E., Bhasale, A. L., and Cohen, M. (2014). Garlic for the common cold. Cochrane Database of Systematic Reviews.

Londhe, V. (2011). Role of garlic (Allium sativum) in various diseases: An overview. angiogenesis 12, 13.

Meher, S., and Duley, L. (2006). Garlic for preventing pre-eclampsia and its complications. Cochrane Database of Systematic Reviews.

Nasiru, A., Hafsat, I., Mohammad, M., and Sabo, A. (2012). Hepatoprotective effect of garlic homogenate co-administered with antituberculosis drugs in ratliver enzymes. International Journal of Bioscience, Biochemistry and Bioinformatics 2, 354.

Rao, R. R., Rao, S. S., Natarajan, S., and Venkataraman, P. (1946). Inhibition of Mycobacterium tuberculosis by garlic extract. Nature 157, 441-441.

Reinhart, K. M., Coleman, C. I., Teevan, C., Vachhani, P., and White, C. M. (2008). Effects of garlic on blood pressure in patients with and without systolic hypertension: a meta-analysis. Annals of Pharmacotherapy 42, 1766-1771.

Rivlin, R. S. (2001). Historical perspective on the use of garlic. The Journal of nutrition 131, 951S954S.

Rose, K. D., Croissant, P. D., Parliament, C. F., and Levin, M. B. (1990). Spontaneous spinal epidural hematoma with associated platelet dysfunction from excessive garlic ingestion: a case report. Neurosurgery 26, 880-882.

Ross, Z., O'Gara, E. A., Hill, D. J., Sleightholme, H., and Maslin, D. J. (2001). Antimicrobial properties of garlic oil against human enteric bacteria: evaluation of methodologies and comparisons with garlic oil sulfides and garlic

[Citation: Ashfaq, F., Ali, Q., Haider, M.A., Hafeez, M.M., Malik, A. (2021). Therapeutic activities of garlic constituent phytochemicals. Biol. Clin. Sci. Res. J., 2021: 53. doi: https://doi.org/10.54112/bcsrj.v2021i1.53] 
powder. Applied and environmental microbiology 67, 475-480.

Rouf, R., Uddin, S. J., Sarker, D. K., Islam, M. T., Ali, E. S., Shilpi, J. A., Nahar, L., Tiralongo, E., and Sarker, S. D. (2020). Anti-viral potential of garlic (Allium sativum) and it's organosulfur compounds: A systematic update of pre-clinical and clinical data. Trends in Food Science \& Technology.

Sallam, K. I., Ishioroshi, M., and Samejima, K. (2004). Antioxidant and antimicrobial effects of garlic in chicken sausage. LWT-Food Science and Technology 37, 849-855.

Shimon, L. J., Rabinkov, A., Shin, I., Miron, T., Mirelman, D., Wilchek, M., and Frolow, F. (2007). Two structures of alliinase from Alliium sativum L.: apo form and ternary complex with aminoacrylate reaction intermediate covalently bound to the PLP cofactor. Journal of molecular biology 366, 611-625.

Thangaratinam, S., Langenveld, J., Mol, B. W., and Khan, K. S. (2011). Prediction and primary prevention of pre-eclampsia. Best practice \& research Clinical obstetrics \& gynaecology 25, 419-433.

Tsai, C.-W., Chen, H.-W., Sheen, L.-Y., and Lii, C.K. (2012). Garlic: Health benefits and actions. BioMedicine 2, 17-29.

Urs, W., Shaw, M. L., and Lancaster, J. E. (1994). Effect of freezing upon alliinase activity in onion extracts and pure enzyme preparations. Journal of the Science of Food and Agriculture 64, 315-318.

Uzun, L., Tuba Dal, M., Yürek, M., Açıkgöz, Z. C., and Durmaz, R. (2019). Antimicrobial activity of garlic derivatives on common causative microorganisms of the external ear canal and chronic middle ear infections. Turkish archives of otorhinolaryngology 57, 161.

Vijayakumar, S., Malaikozhundan, B., Saravanakumar, K., Durán-Lara, E. F., Wang, M.-H., and Vaseeharan, B. (2019). Garlic clove extract assisted silver nanoparticleAntibacterial, antibiofilm, antihelminthic, antiinflammatory, anticancer and ecotoxicity assessment. Journal of Photochemistry and Photobiology B: Biology 198, 111558.

Wang, J., Cao, Y., Sun, B., Wang, C., and Mo, Y. (2011). Effect of ultrasound on the activity of alliinase from fresh garlic. Ultrasonics sonochemistry 18, 534-540.

Yin, M.-C., and Cheng, W.-s. (2003). Antioxidant and antimicrobial effects of four garlic-derived organosulfur compounds in ground beef. Meat Science 63, 23-28.

Zhou, J. Q., and Wang, J. W. (2009). Immobilization of alliinase with a water soluble-insoluble reversible $\mathrm{N}$-succinyl-chitosan for allicin production. Enzyme and Microbial Technology 45, 299-304.

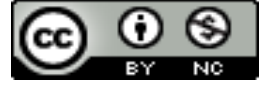

Open Access This article is licensed under a Creative Commons Attribution 4.0 International License, which permits use, sharing, adaptation, distribution and reproduction in any medium or format, as long as you give appropriate credit to the original author(s) and the source, provide a link to the Creative Commons licence, and indicate if changes were made. The images or other third party material in this article are included in the article's Creative Commons licence, unless indicated otherwise in a credit line to the material. If material is not included in the article's Creative Commons licence and your intended use is not permitted by statutory regulation or exceeds the permitted use, you will need to obtain permission directly from the copyright holder. To view a copy of this licence, visit http://creativecommons.org/licen ses/by/4.0/.

(C) The Author(s) 2021

[Citation: Ashfaq, F., Ali, Q., Haider, M.A., Hafeez, M.M., Malik, A. (2021). Therapeutic activities of garlic constituent phytochemicals. Biol. Clin. Sci. Res. J., 2021: 53. doi: https://doi.org/10.54112/bcsrj.v2021i1.53] 